\title{
Smith v. Clark and Clark v. Smith: Eighteenth-Century Scottish Doctors in Dispute
}

\author{
LEAH LENEMAN*
}

Understanding of the mechanisms of the body and effective medical intervention had made little progress since antiquity, but in the mid-eighteenth century doctors enjoyed much confidence amongst the populace and could earn a good living. ${ }^{1}$ At the same time, individuals of all classes took enormous interest in matters of health and felt themselves able to participate in their own diagnoses and cures. By tracing the voluminous correspondence on medical matters in the Gentleman's Magazine, Roy Porter has shown not only that individuals were familiar with such matters but that this familiarity was "integral to the public role of the well-informed, publicspirited and responsible layman". ${ }^{2}$

But what if doctors disagreed? How was the layman to know whom to trust? Certain personalities would have inspired more confidence; "successes" would have been spread by word of mouth; alternative opinions would have been sought. Disagreements and rivalries between doctors cannot have been that rare, but uncovering evidence of them is not easy. ${ }^{3}$ Roy Porter has documented a dispute between a "quack" and a "scion of medical orthodoxy". ${ }^{4}$ This paper looks at a much lower

${ }^{*}$ Leah Leneman, $\mathrm{PhD}$, lecturer at the Department of Economic and Social History of the University of Edinburgh, submitted this article shortly before she died in December 1999.

In her original acknowledgments, Dr Leneman expressed her gratitude to the Faculty Group of Law and Social Sciences, University of Edinburgh, for the fellowship that supported her research into defamation in eighteenth-century Scotland, and to her department for affording the necessary facilities. She also thanked the staff at West Register House whom she found unfailingly helpful, and Graham Sutton whose comments on an earlier draft of this paper improved the final version.

${ }^{1}$ Roy Porter, Disease, medicine and society in England 1550-1860, Basingstoke, Macmillan Education, 1987, pp. 14-15, 40; David Hamilton, The healers: a history of medicine in Scotland, Edinburgh, Canongate, 1981, pp. 97-8, 136.
${ }^{2}$ Roy Porter, 'Lay medical knowledge in the eighteenth century: the evidence of the Gentleman's Magazine', Med. Hist., 1985, 29: 138-68, p. 163.

${ }^{3}$ One source is the eighteenth-century diaries, as diarists "recorded dissent between practitioners, in which the senior man usually triumphed by changing the prescribed treatment and by impugning the other man's competence". Joan Lane, "The doctor scolds me": the diaries and correspondence of patients in eighteenthcentury England', in Roy Porter (ed.), Patients and practitioners: lay perceptions of medicine in pre-industrial society, Cambridge University Press, 1985, pp. 205-48, p. 220.

${ }^{4}$ Roy Porter, "I think ye both quacks": the controversy between Dr Theodor Myersbach and Dr John Coakley Lettsom', in W F Bynum and Roy Porter (eds), Medical fringe and medical orthodoxy, 1750-1850, London and Sydney, Croom Helm, 1987, pp. 56-78. 


\section{Leah Leneman}

level feud. It is in one way a classic case of a well-established small town practitioner finding himself challenged by a young rival, which could have occurred in any town and century, but at the same time it is a snapshot of both medical and lay attitudes at a particular point in time, the 1750s.

It is based on two opposing cases of "scandal", i.e. defamation, raised before Edinburgh Commissary Court in 1756. Unlike English law, Scottish law did not require someone raising such a suit to prove that he or she had suffered specific harm; it was enough that the defamatory words could potentially have caused personal or professional hurt. ${ }^{5}$ As one lawyer in such a case argued, defamation constituted words which might hurt a man's livelihood such as "to call a tradesman a Bankrupt or Physician a Quack or a Lawyer a Knave". ${ }^{6}$

Neither of the two men was a qualified physician; both were surgeon-apothecaries, who were found all over Scotland and have been termed the first "general practitioners", offering a wide range of services. ${ }^{7}$ James Smith was born in the burgh of Borrowstounness, more generally known as Bo'ness (with a population in 1755 of 2,668 ) and returned there to practise medicine for some thirty years. In 1752 two new surgeons took up residence. Duncan Glasford, who was caught up in the quarrel, seems to have rubbed along well enough with the older doctor. John Clark, on the other hand, was clearly a far more thrusting character who was being specifically called by patients for a second opinion. One witness testified that when he and his wife proposed sending for Clark, Smith said he would not remain to consult with him for Clark disapproved of everything he did, and he went "off in a huff". There may well have been religious disagreements as well, for the younger man, Clark, referred to Smith's "Hypocriticall pretensions to Religion", while Smith insisted that Clark "was an Atheist or a Deist at least".

The first of the two suits was raised by Clark against Smith (initially it was against Glasford as well, but the latter was cleared) in July $1756 .{ }^{8}$ Clark had performed an operation on the son of a collier of the Duke of Hamilton, cutting a stone from the "Urethra of his Penis". The parents of the child (who was eighteen months old) offered thanks to God in church for the success of this "dangerous" operation. According to Smith, several people asked his opinion of this, and the version of events he was given was that the child

had been Cut of a stone in ye Bladder without any other Assistance than being layd on a Womans knees, a stone extracted as big as a kidney bean from a Wound about the ffundament no bigger than an ordinary blooding in the Jugular, That the Child was so well after the operation as to run through the room with it's [sic] Comrades in about two hours, after having been Carried home from the place where the operation was performed at some distance, That the Child was quite well and the wound whole in two or three days, and no urine running through the wound but passing the ordinary way.

\footnotetext{
${ }^{5}$ John Borthwick, Treatise on the law of libel and slander, Edinburgh, $\mathrm{W} \& \mathrm{C}$ Tait and $\mathrm{J} \&$ W T Clarke, 1826, pp. 2-3.

${ }^{6}$ National Archives of Scotland (hereafter NAS) $\mathrm{CC} 8 / 5 / 18$.
}

\footnotetext{
${ }^{7}$ Hamilton, op. cit., note 1 above, p. 98.

${ }^{8}$ NAS CC8/6/22. Unless otherwise stated, all further material in this paper comes from these process papers.
} 


\section{Smith v. Clark and Clark v. Smith}

Smith's reply to those who asked his opinion was that "the thing was nonsense \& Impossible And that if any man pretended that he had cutt the said Child in the perineum it was false, for the stone was certainly in his hand and he had only scratched the Child's hip and covered it with a plaister".

Subsequently the minister, Mr Baillie, advised Smith that the cut was not in the bladder but in the urethra of the penis. Smith conceded that he had been misinformed, "and that what had been say'd of the childs so speedy recovery to his Urining through the Ordinary passage was extremely possible, as in fact such an operation is neither Difficult nor Dangerous". The minister attempted to persuade Smith to recant his earlier comments and apologize, and Clark to accept his apology, but the pride of both men prevented such a reconciliation, and the case proceeded to court.

Smith insisted he had not propagated a falsehood, all he did was give an opinion when asked "by people who had been made to believe a report of the pursuer's having performed something which to them appeared wonderfull \& extraordinary":

a Solemn Thanksgiving was made on behalf of the Child on a Supposition of its having recovered from a Dangerous operation; seeing the making an Incision in the Urethra penis \& extracting a stone which had protruded into it from the Bladder could not be Considered a Dangerous operation, or as a matter of such moment to return thanks publickly in the Church upon that Account; no more than opening a Vein \& letting blood at the Arm coud be looked on in that light.

Clark responded that the child had, in fact, been a patient of Smith, but Smith had refused to be present, and "as soon as the operation was over, He sent for a sight of the Stone which had been Extracted from the Child, \& without Examining further into the Matter proclaimed That it had been an Imposture, That the pursuer had only scratched the Child with a Lancet, \& that having a stone concealled in his pocket, he had given out that this was the stone, he had Extracted from the Child". Mr Baillie, the minister,

Observed a Wound in the penis where the pursuer said the operation had been performed And at the same time saw a stone about the Bigness of a Large fitchy pea, which both the pursuer and the childs mother said had been Extracted from him, And which stone the deponent observed to be of the same kind (as he thought) with other stones which he knew to have been passed by adult persons. That the pursuer at the same time described to this deponent the manner how he had performed the operation, and owned that there was no merit in it for that the Cure was in finding out the disease.

The child's mother told him that for forty-eight hours beforehand the child had passed no urine, and the minister testified that Clark told him that "the Child would have died in a few hours if the operation had not been performed And that he would have Bursted". John Inglis, an eighteen-year-old "student of physick" in Edinburgh, assisted in the operation and agreed that the child's bladder was greatly distended.

But Smith continued to spread his version of the story. Alexander Hodge, a sailor, came home from Greenland with a toothache and asked Smith to extract the tooth, "to which Mr Smith said he could do it as soon and as easily as Mr Clerk made the operation on the Coaliers child for the Gravel, ffor That he pricked the child in 


\section{Leah Leneman}

the arse and frighted the child and made it to pass urine". And another witness was hailed by Smith in the street and told that

all that passed was that the childs mother having called Mr Clarke into a publick house to see the child and she having taken the child upon her knee Mr Clarke scratched the childs backside to make it cry and then having pretended to make an incision upon it, he then showed a Little stone which he pretended he had taken from the child when he had Cutt it But that it was all a farce and the returning thanks in the Church was a piece of solemn mockery.

Smith called his own exculpatory witnesses, ranging from locals on his side to $\mathrm{Dr}$ James Walker, a physician from Edinburgh, who testified that "according to the Common acceptation of the phrase, Cutting for the Gravel or stone, it always implies That the stone is Cut from the Bladder", and that he thought the operation as described by Mr Inglis "was not attended with any great danger". (But, in answer to a question by Clark's lawyer, he agreed that such a stone "if not extracted would occasion the death of the patient and thinks the stone abovementioned in a child of eighteen months old would totally obstruct the passage".) At the end of this case the commissaries (judges) found it proven that Smith

did Injuriously calumniate the pursuer John Clark by misrepresenting the operation performed by the said John Clark ... and asserting that the pursuer had a stone concealed in his pocket and having only scratched the boys backside he gave out that that was the stone which he had cut out from the boy but that it was all a farce.

They judged Smith liable to Clark for damages and expenses of $£ 20$, and he had to pay a fine of $£ 6$ to the treasurer of the Orphan Hospital in Edinburgh and sign a recantation. But in the meantime the case of Smith against Clark was also being heard.

Clark's defamation of Smith was more serious than that of falsifying an operation. It centred round two merchant families, the Scrimgeours and the Addisons, and claimed that by overdosing them with opium Smith had caused the death of three of the Scrimgeour children and nearly killed both Mrs Scrimgeour and Mrs Addison. Although he claimed that Smith raised his defamation action only as retaliation, that was clearly not so, for Clark confronted Smith in public, asking if he was willing to acknowledge "that you gave Mrs Addison poison and murdered her, Doe you know that opium is a poison you Blockhead?", and continued, "if you Don't Confess the murder and poison I shall pursue you before the Justiciaray and there get you declared incapable and opium and Mercury taken from your Shop and you forever after Discharged the use of them".

Mrs Scrimgeour's evidence was not particularly relevant to the charge (according to the evidence, Smith raised a separate defamation action against Scrimgeour, which might have revealed more about this family, but the process papers do not appear to have survived); it does, however, demonstrate a lay person shopping around as a consumer for the best medical care. One of her children had a "looseness" and was given "tincture of Rhubarb" by Smith, which he took for nine days but grew worse. In this case, Clark said to her that though he had no way of knowing what was in the tincture it did smell of rhubarb, but Mrs Scrimgeour said to him and 


\section{Smith v. Clark and Clark v. Smith}

others that "Mr Smith was the occasion of poysoning her child By directing the medicine in the Bottle above mentioned to be given to him, for that thereafter he grew worse and worse every day".

Mrs Scrimgeour followed this with a lengthy story about her husband's treatment by Smith, starting with an itch, an ointment that did no good, some salve which she rubbed into him, and then fever, followed by pains. Smith then "bled him several times", though Mrs Scrimgeour protested "That she thought her husband being a thin man, was not able to stand these Bloodings, and the physick that he had given him at the same time, upon which Mr Smith flew in a passion and said he would Blood \& physick him as much as he thought proper". About three days after this, Scrimgeour "complained much of a Gripping pain in his stomach and side which he was afraid would seize his heart, And thereupon told Mr Smith That he inclined to have the assistance of a physician, to which Mr Smith said there was no occasion for it, as the pains were Rheumatick and that he knew how to treat that disease as well as any physician". But her husband's pains increased, and eventually the physician sent an assistant, a Mr Drummond, "who ordered him some medicines and directed him to drink broths and others for promoting sweating, and discharged Blooding him any more, and making use of the ointment". Scrimgeour soon recovered.

Subsequently, Mrs Scrimgeour herself "Laboured under a Disease in her stomach" and was given drugs for it (we are not told what the disease or the drugs were). As "she was not the Better for these Drugs" she went to Edinburgh and consulted "Mrs Knox the Midwife who directed her to take certain medicines which were simple". When she returned and told Smith, he scorned them as "no more use than Holy water". She had miscarried shortly before going to Edinburgh and was convinced that "the Cause of her parting with child was the drugs that Mr Smith administred to her". After the miscarriage, Smith told her "that he thought she had an ulcer in her Belly and directed her to take purging medicines and especially mercury \& that if she did not take mercury there would be no more help for her, and she would vomit up the ulcer". It was at this point that she sent for Clark, who attended her until she recovered, and she told the court that she "Really Believes that the medicines prescribed by him were, under God the means of her Recovery".

The Addison case was different. Mrs Addison, after childbirth, had difficulty sleeping, and Smith gave her some opium, which "had the desired effect". Soon after that she had a "looseness" and was again given some opium by Smith. At first she

thought herself quite easy and well therewith but very soon thereafter her head turned giddy and she thought the Chairs and every thing else in the Room was moving And she the Deponent had no less than two fainting fitts and imagined herself dying, and for that reason sent for her Husband who desired her not to be apprehensive for that these were only the effects of the opium.

But when Smith was sent for he insisted "that what had happened could not be the effect of the opium, and that if she . . could but compose herself he hoped she would get rest and would turn better". In fact she grew worse, and remembered nothing of what happened in the intervening two days until she wakened and was 


\section{Leah Leneman}

told by Clark that "the great distress which she had been in was owing to the poisonable dose of opium which she had got from the pursuer".

Mrs Addison's husband confirmed that even after his wife "turned delirious" Smith was keen to give her more opium and said that she "behooved to have opium in every thing she got untill she sleept". When it appeared that her life was in real danger, Clark was sent for, and when he "looked to her Eyes he said, she has got an over dose of opium, and said that she should have no more, But should have every thing that was cooling". Smith was still suggesting that more opium be given to her, and it was agreed that a doctor should be sent for from Edinburgh, but Clark told Mr Addison that if she were given chicken broth the effects of the opium would wear off in a few hours, which was what happened. ${ }^{9}$

There seems little doubt that Clark's evaluation was correct, and that Smith really was criminally irresponsible. Had Clark sent for two Edinburgh physicians to look into Smith's use of dangerous drugs, as he was threatening to do, he could have sustained his defence that "What he Did was Entirely with a View to the General Good of Mankind, and to prevent the ffatal Effects, \& Mischief of such Capitall Medicines being Injudiciously Dispensed for the future". Instead he went charging up to Smith, who was standing on the shore of Bo'ness along with the Duke of Hamilton's chamberlain and others, and called all those present to be witnesses that he required Smith to acknowledge publicly that he had poisoned Mrs Addison, and that if he failed to do so Clark would have him condemned for poisoning her and killing the Scrimgeour children.

That he was an Ignorant Scoundrell in his profession and had got his Education from some old wife, and that he knew no more the use of opium or its powers or virtues than several persons that had then joined the company and were standing by.

When Smith replied that Clark would have to answer for the abuse he had given him that day, "Mr Clark seemed to fall into a great passion and said that the pursuer was a two faced praying knave, and made a proffession of Religion to hide and conceal the murders he committed, and sanctifyed his poysoning practice by prayer". The commissaries therefore found it proven that Clark

was Guilty of an Atrocious injury \& Calumny agt James Smith the pursuer in attacking him upon the streets of Bo-ness ... and Before many persons accusing him of having poisoned Mrs Addison and Murdered Mr Scrimgeors children, and calling him an Ignorant Scoundrell, Blockhead, Hypocrite and Villain.

They awarded even higher damages: $£ 30$, plus a $£ 6$ fine payable to the treasurer of the poor's house in Edinburgh, and naturally Clark too had to appear in open court to beg pardon and sign a public recantation.

Neither of the participants appears in a favourable light, but while it is not an edifying tale, it does offer a unique glimpse into medical practices and attitudes in a Scottish town in the middle of the eighteenth century.

\footnotetext{
${ }^{9}$ Joan Lane found some eighteenth-century English diarists recording over-prescription of opiates; Lane, op. cit., note 3 above, p. 221.
} 